\title{
Landslides, Shocks, and New Global Rules: \\ The US and Western Europe in the New International History of the 1970s
}

\author{
Michele Di Donato ${ }^{1}$
}

\section{Introduction}

Research on the international history of the 1970s has been flourishing in the last two decades. Through a search on Google Books N-Gram Viewer (an obviously imperfect, yet illustrative instrument) one can virtually single out the moment, in the early 2000s, when a new narrative of the late $20^{\text {th }}$ century took hold, so much so that writing (and reading) the words 'since the 1970s' became more common than writing (and reading) 'since the 1960s' (the relatively recent 1980s still lag behind, and references to earlier decades appear to be declining) $)^{2}$. To take but a prominent example, the formula 'since the 1970s' appears some twenty times in the pages of Thomas Piketty's economic history bestseller Capital in the Twenty-First Century, and the book counts almost fifty more occurrences of analogous expressions referring to the decade as a watershed ${ }^{3}$.

The success of an historical periodisation, not to speak of its accuracy or efficacy, is not something that can be measured in numbers, however sophisticated the algorithms we use. Nevertheless, Google-powered statistics and homespun guesstimates all seem to hint at a rather established trend. Stating that the 1970s represent a watershed moment has become a commonplace that any student of contemporary history can corroborate with a litany of references to events and transitions that took place or began in the years of bell-bottoms and disco music: be it the sweeping changes of the world economy (the collapse of the Bretton Woods architecture, the development of the international financial markets, the oil shocks, stagflation and low productivity), the decline of the Western industrial society, or China's rapprochement with the US and post-Mao economic reorientation, to mention just a few.

As their interest in the decade surged, historians began to engage in a battle of sorts with public memory: the 1970s, they argued, were not just 'years of crisis' as they tended to be

This project has received funding from the European Union's Horizon 2020 research and innovation programme under the Marie Skłodowska-Curie grant agreement No 704507

${ }^{2}$ https://goo.gl/UMz15C (last accessed 22 March 2017).

3 Thomas Piketty, Capital in the Twenty-First Century, (Cambridge, MA, and London: The Belknap Press of Harvard University Press, 2014). 
remembered by those who had experienced them ${ }^{4}$. Of course, no historian of the US questioned the disheartening legacy of the Watergate scandal or the dreariness of queues at ill-supplied gas stations, not to speak of the long and gloomy shadow cast by the Vietnam War; no one in Western Europe denied the reality of low economic growth and high inflation; nor was the retreat of democracy in Latin America in dispute. All this, however, was considered only part of the story. Some pointed to the presence, alongside the 'crosscurrents of crisis' of the decade, of strong and lively threads of civic engagement, embodied by 'optimistic reformers' who were able to leave a durable mark on society - the global inroads of women's rights, environmentalism and human rights activism being quintessential examples ${ }^{5}$. Others would underline the emergence of a more interdependent and interconnected world, also as a result of technological advancements ${ }^{6}$. More broadly, as a French historian effectively put it in the title of a textbook on the history of the decade, the 1970s represented the 'end of a world' but also, in many ways, 'the beginning of our modernity'

The aim of this article is to provide a panorama of some of the key currents of research on the history of the 1970s, to examine different historiographical perspectives and to discuss open questions and possible future developments. The article will focus on scholarship produced in the last two decades, when the 1970s have increasingly come under the spotlight - as a result of the gradual declassification of public and private records, but also of the consolidation of new historiographical approaches and sensibilities. The vast majority of the works we will examine fall under the rubric of 'international history'. Long perceived as the preserve of an unabashedly old-fashioned political history approach, this sub-discipline has in fact been transformed by the espousal of a plurality of perspectives (social, cultural, economic, environmental, etc.), the broadening of its subjects of study, the increasing focus on non-state actors and global and transnational processes, as well as the integration of the major

\footnotetext{
${ }^{4}$ Niall Ferguson, 'Crisis, What Crisis? The 1970s and the Shock of the Global', in Niall Ferguson, Charles S. Maier, Erez Manela, Daniel J. Sargent (eds.), The Shock of the Global: The 1970s in Perspective, (Cambridge, MA, and London: The Belknap Press of Harvard University Press, 2010), 1-21. For other examples, see, among many others, James T. Patterson, Restless Giant: The United States from Watergate to Bush vs. Gore, (Oxford: Oxford University Press, 2005), 13-44; Lawrence Black, Hugh Pemberton and Pat Thane (eds.), Reassessing 1970 s Britain, (Manchester: Manchester University Press, 2013).

${ }^{5}$ Thomas Borstelmann, The 1970s: A New Global History from Human Rights to Economic Inequality, (Princeton: Princeton University Press, 2012). For a classic coeval account of the rise of new 'post-materialist' values and social movements see Ronald Inglehart, The Silent Revolution: Changing Values and Political Styles Among Western Publics, (Princeton, NJ: Princeton University Press, 1977).

${ }^{6}$ Akira Iriye, Global Community: The Role of International Organizations in the Making of the Contemporary World, (Berkeley: University of California Press, 2012), 126-56; Marc Levinson, The Box: How the Shipping Container Made the World Smaller and the World Economy Bigger, (Princeton: Princeton University Press, 2006); David Reynolds, One World Divisible: A Global History Since 1945, (London: Penguin Books, 2000), 494-538. ${ }^{7}$ Philippe Chassaigne, Les années 1970: Fin d'un monde et origine de notre modernité, (Paris: Armand Colin, 2012).
} 
historiographical 'turns' of the last few decades. These innovations have been crucial to the emergence of what has been defined as a 'New International History', wide-reaching in its focus, ecumenical in its approaches, but possibly held together by an enduring preoccupation with political power and its role in the international arena ${ }^{8}$. It is this perspective we will adopt in our analysis.

At the same time, this historiographical exploration cannot be but a partial one, constrained by space and by this author's competences. The article's geographical focus will be on the United States and Western Europe, whose experience of the 1970s, as we shall see, played a non-negligible role in defining important aspects of the global legacy of that decade. While the choice of this vantage point also reflects a recent tendency to reappraise the significance of Europe in the international history of the last quarter of the $20^{\text {th }}$ Century ${ }^{9}$, this does not lessen the crucial importance of examining events 'in global perspective' - to use a conventional expression. The areas on which this article will focus will be considered as regions integrated into an increasingly interdependent world, where different historical actors, at different scales, both partook in and experienced the effects of broader trends and transformations.

The article is composed of five sections. After a brief outline of the key periodisations and narratives of the history of the 1970s, the three central sections discuss recent trends in the literature on US foreign relations, Western Europe, and the global political-economic transformations that began at the end of the decade, respectively. The conclusion puts forward some considerations on the significance of this period for the recent global and transnational 'turns' in historical studies.

\section{What kind of transition?}

When did 'the 1970s' begin, and when did they end? The answer, of course, depends on what we single out as the defining features of the decade. Some authors refer - either explicitly or implicitly - to a 'short decade', squeezed between the landmark dates of 1973, when cracks

\footnotetext{
${ }^{8}$ For a forum on the history and the current state of the sub-discipline see the special issue 'Storia internazionale, transnazionale, globale: una discussione', eds. Mario Del Pero and Guido Formigoni, Ricerche di Storia Politica, 3, 2016 (see the editors' conclusion for the definition of 'New International History'; Del Pero and Formigoni, 'Spunti di conclusione: per una New international history', 301-307). On the impact of the cultural and global 'turns' (and its limits) see David Reynolds' contribution to the same volume ('Turn, Turn, Turn...', 265-268), as well as his 'International History, the Cultural Turn and the Diplomatic Twitch', Cultural and Social History, 3:1 (2006), 75-91.

${ }^{9}$ See Federico Romero, "Cold War Historiography at the Crossroads", Cold War History, 14, 4 (2014), 685-703.
} 
in many pillars of the postwar order became apparent (as a consequence of events such as the oil shock, the definitive shift to a system of floating exchange rates, and the humiliating retreat of US troops from Vietnam) and 1979, when the signs that an old world was coming to an end became impossible to ignore (events such as the election of Margaret Thatcher in Britain, the 'Volcker Shock' in the US, the Soviet invasion of Afghanistan, the beginning of Deng's reforms in China, the fall of the Shah and the Islamist turn of the revolution in Iran, together with a new dramatic hike in oil prices, all had global repercussions that pointed in that direction) ${ }^{10}$. Others argue that some of the themes that are usually associated with the 1960s (from big government to social mobilisation) 'did not only persist into the 1970s; they prospered during the 1970s', so much so that the decade can be portrayed as the second act of a 'long 1960s'11. References to the 'long 1970s', however, are now far more frequent in works of international history and beyond $^{12}$. The 'long 1970s' can be defined as an age of transition that began with the social and international turmoil of the late 1960s and did not end before the early-mid 1980s, when transformations started being assimilated and global responses began to take shape. Just to what extent this transition from an 'old' to a 'new' order has been completed it remains a matter of debate, and some argue that the historical sequence that commenced during the 'long decade' is probably not over yet ${ }^{13}$.

The question naturally arises: what kind of transition are we talking about? Comparing the world order that was fashioned at the end of the Second World War to the one that emerged out of the long 1970s, the differences are striking. In spite of its apparent resurgence during the ephemeral 'Second Cold War' of the early 1980s, bipolarism was less and less relevant as an organizing principle of international relations, and would eventually dissolve in the space of a few years. The impact of developments whose dynamics transcended East-West logics grew tremendously: One can think of the energy question or of North-South relations as two relevant examples, not to speak of what appeared to many as the most important development of the decade, the gradual exhaustion of the postwar model of economic growth. Intra-bloc cohesion

\footnotetext{
${ }^{10}$ Borstelmann, The 1970s, 6-7; Christian Caryl, Strange Rebels: 1979 and the Birth of the 21 ${ }^{\text {st }}$ Century, (New York: Basic Books, 2013).

${ }^{11}$ Stephen Tuck, 'Introduction: Reconsidering the 1970s - The 1960s to a Disco Beat?', Journal of Contemporary History, 43, 4 (2008), 617-620.

12 Bruce J. Schulman, The Seventies: The Great Shift in American Culture, Society, and Politics, (Cambridge, MA: Da Capo Press, 2002): Ferguson, 'Crisis, What Crisis ?', 3 ; Poul Villaume, Rasmus Mariager and Helle Porsdam (eds.), The 'Long 1970s': Human Rights, East-West Détente and Transnational Relations, (London and New York: Routledge, 2016); Aaron Brenner, Robert Brenner, Calvin Winslow (eds.), Rebel Rank and File: Labor Militancy and Revolt from Below During The Long 1970s, (London: Verso, 2010).

${ }^{13}$ Anselm Doering-Manteuffel and Lutz Raphael, Nach dem Boom: Perspektiven auf die Zeitgeschichte seit 1970, (Göttingen: Vandenhoeck \& Ruprecht, 2012²), 7; Daniel T. Rodgers, Age of Fracture, (Cambridge, MA: Belknap Press of Harvard University Press, 2011).
} 
was declining, too, as shown by transatlantic crises and by the frequent tensions between Moscow and its allies. More broadly, the very notion that it was states, or at least the most powerful among them, which controlled, influenced and moulded the international arena, became increasingly dubious as transnational actors and global developments hit the scene, from multinational corporations and global finance to acid rain and anti-nuclear activism.

If the importance of these developments can hardly be disputed, historical interpretations do vary markedly depending on the thematic and chronological perspective each author privileges. Narratives that focus on economic transformation and its consequences are best epitomised by Eric Hobsbawm's classic Age of Extremes. According to its famous periodisation, a 'golden age' of (Western) capitalism came to an end with the economic difficulties of the 1970s, and a devastating 'landslide' began, leading to decades of 'instability and crisis' ${ }^{14}$. While technological advances favoured a restructuring of production that caused substantial losses of manufacturing jobs in the West, markets' globalisation and the growing role of transnational finance contributed to shaping an unstable and crisis-prone economic environment. Percolating to the realm of politics, these tensions led to a general decline in the fortunes of state-centred interventionism, often to the benefit of various brands of 'neo-liberalism'; a pattern that was then replicated on a gigantic scale in the collapse of the centrally planned economies of the USSR and its allies.

Among the critics of this approach, Charles Maier turned the spotlight on Hobsbawm's periodisation choices. Looking back to the eclipsing century in the emblematic year 2000, he argued that "to focus on the "twentieth century" as such obscures one of the most encompassing or fundamental sociopolitical trends of modern world development, namely the emergence, ascendancy, and subsequent crisis of what is best labeled "territoriality". Maier thus identified an epoch of modern territoriality, beginning around the $1860 \mathrm{~s}$, whose key attribute was a configuration by which 'territories to which ordinary men and women tended to ascribe their most meaningful public loyalties ... also provided the locus of resources for assuring their physical and economic security'. The turning point of the 1970s assumed a new meaning in this framework. As the moment in which the process that we now call 'globalisation' began to void national space of its significance as a crucial basis for the organisation of collective security and economic activity, the decade marked not just a rupture in the political and ideological $20^{\text {th }}$ century, but the endpoint of a much longer historical sequence ${ }^{15}$. This interpretation, which

\footnotetext{
${ }^{14}$ Eric J. Hobsbawm, The Age of Extremes: The Short 20th Century, 1914-1991, (London: Abacus, 1994), 403.

${ }^{15}$ Charles S. Maier, "Consigning the Twentieth Century to History: Alternative Narratives for the Modern Era", American Historical Review, 105, 3 (2000), 807-831, here 807, 823. On territoriality (or 'territorialism') see also
} 
Maier later developed in essays and monographs ${ }^{16}$, has influenced historical research in many ways ${ }^{17}$. Some of its crucial traits were discernible in the much-cited 2010 edited volume The Shock of the Global, whose chapters showcased a new approach to the history of the 1970s by focusing on the often-traumatic impact of the accelerating dynamics of interdependence and globalisation $^{18}$.

While this has become the most common framework in which to analyse the international history of the 1970s and grasp its long-term significance, most scholars would agree that it is no less important to also take into account the coordinates that contemporaries employed to understand their world, which remained largely wedded to an international system ostensibly made up of sovereign states. This tension, between the increasing relevance of global forces and the state-based articulation of the international arena, permeated the 1970s. In order to understand the epochal transition that took place during that decade it is therefore necessary to focus both on the host of difficulties, transformations and novelties in the international system and on the changing relationship between global and national equilibria. Since the Cold War was still perceived as the crucial axis around which international relations were organised, understanding its interaction with the processes of 'globalisation' is also crucial ${ }^{19}$. The remainder of this article will try to do so by singling out, and discussing, three main strands of research.

\section{The United States in a changing world}

As the most influential actors of the international system, the United States and the Soviet Union have long catalysed the attention of observers and historians alike. From this point of view, the 1970s has been considered, first and foremost, as the decade of the apogee and fall of East-West détente, the US opening to China, Washington's long goodbye to Vietnam, and Middle East crises and diplomacy. Strategic parity between the superpowers, by then perceived to be irreversible, and the doctrine of Mutual Assured Destruction, provided the context in

Giovanni Arrighi, The Long Twentieth Century: Money, Power, and the Origins of our Times, (London: Verso, 1994).

${ }^{16}$ See especially Charles S. Maier, Once within Borders: Territories of Power, Wealth, and Belonging Since 1500, (Cambridge, MA-London: The Belknap Press of Harvard University Press, 2016).

${ }^{17}$ See Manu Goswami et al., "AHR Conversation: History after the End of History: Reconceptualizing the Twentieth Century History after the End of History", The American Historical Review 121, 5 (2016): 1567-1607.

${ }^{18}$ Niall Ferguson, Charles S. Maier, Erez Manela, Daniel J. Sargent (eds.), The Shock of the Global.

${ }^{19}$ See Federico Romero, Storia della guerra fredda. L'ultimo conflitto per l'Europa, (Turin: Einaudi, 2009), 9-10. 
which these developments took shape. The Cold War great game was still on, although some of its features were changing ${ }^{20}$.

Several accounts of US foreign policy have taken this approach and applied it to the various Cold War theatres ${ }^{21}$. Superpowers' détente, in particular, has been the object of numerous studies, whose focus soon extended beyond great power politics to include matters such as domestic-foreign policy interactions or the impact on policymaking of the youth uprisings of the late $1960 \mathrm{~s}^{22}$. The centralisation of decision-making during the 'imperial presidency' of Richard Nixon, together with the apparently inexhaustible interest generated by his key foreign policy advisor, Henry Kissinger, have however justified a continuing concentration on the role of top-echelon officials ${ }^{23}$.

Yet, East-West diplomacy took place against the backdrop of a crucial transformation of the two superpowers. While wrestling for world influence and negotiating a new modus vivendi, the two giants of the postwar era were also grappling with a profound alteration of their domestic structures and international role. In the West, three different but interrelated questions epitomise the changing nature of American power: namely, international economic and monetary relations, energy policy, and the rise of human rights concerns.

In what is probably the best available study of US foreign policy during the 1970s, Daniel Sargent has convincingly shown how Washington policymakers who had built their careers and their worldviews within a Cold War framework struggled, with mixed results, to make sense of - and respond to - new challenges that were linked to the emerging globalisation process ${ }^{24}$. The

\footnotetext{
${ }^{20}$ For this interpretation, see Leopoldo Nuti, “On recule pour mieux sauter, or 'What needs to be done' (to understand the 1970s)", in Silvio Pons and Federico Romero (eds.), Reinterpreting the End of the Cold War: Issues, Interpretations, Periodizations, (New York-London: Frank Cass, 2005), 39-51; Barbara Zanchetta, The Transformation of American International Power in the 1970s, (Cambridge-New York: Cambridge University Press, 2014).

21 It would be impossible to provide an exhaustive list of such works. Raymond Garthoff, Détente and Confrontation: American-Soviet Relations from Nixon to Reagan, (Washington, DC: Brookings Institution, 1994) remains a classic and an indispensable reference; Frederick Logevall and Andrew Preston (eds.), Nixon in the World: American Foreign Relations, 1969-1977 (Oxford-New York: Oxford University Press, 2008) provides useful introductions to various aspects of US foreign policy.

${ }^{22}$ Wilfried Loth, Overcoming the Cold War: A History of Détente, 1950-1991, (Basingstoke: Palgrave, 2002); Jeremi Suri, Power and Protest: Global Revolution and the Rise of Détente, (Cambridge, MA: Harvard University Press, 2003); Julian E. Zelizer, "Détente and Domestic Politics." Diplomatic History, 33, 4 (2009), 653-670; Jussi Hanimäki, The Rise and Fall of Détente: American Foreign Policy and the Transformation of the Cold War, (Washington, DC: Potomac Books, 2013).

${ }^{23}$ Jussi Hanhimäki, “'Dr. Kissinger' or 'Mr. Henry’? Kissingerology, Thirty Years and Counting”, Diplomatic History, 27, 5 (2003), 637-676; Jussi Hanhimäki, The Flawed Architect: Henry Kissinger and American Foreign Policy, (Oxford-New York: Oxford University Press, 2004); Jeremi Suri, Henry Kissinger and the American Century, (Cambridge, MA: Harvard University Press, 2007); Mario Del Pero, The Eccentric Realist: Henry Kissinger and the Shaping of American Foreign Policy, (Ithaca, NY-London: Cornell University Press, 2010); Niall Ferguson, Kissinger: The Idealist, 1923-1968, (New York: Penguin Press, 2015).

${ }^{24}$ Daniel J. Sargent, A Superpower Transformed. The Remaking of American Foreign Relations in the 1970s, (Oxford-New York: Oxford University Press, 2015).
} 
events and choices that led to Nixon's momentous decision of suspending the convertibility of dollar into gold in August 1971, and then to the utter dismissal of the Bretton Woods system less than two years later, are paramount in his narrative. In this respect, his account complements an already rich historical literature that insists on the link between Nixon's international monetary policy, on the one hand, and broader economic and foreign policy goals that revolved around the relations between the once seemingly all-powerful American hegemon and its increasingly competitive West European and Japanese allies ${ }^{25}$. While crucial, neither the inherent inconsistencies of the Bretton Woods system, nor the resurgence, spurred by the development of the so-called Eurodollar market, of short-term capital flows that eluded the control of central banks, suffice as explanations of how and why the US ceased to uphold the fundamental pillar of the postwar liberal economic order, the convertible dollar ${ }^{26}$. Emphasised by a deteriorating balance of payments, and exacerbated by tensions over the Vietnam War and the cost of stationing troops in Europe, the perception that the American economy could no longer bear the cost of a system that traded economic concessions (an overvalued dollar and limited access to the markets of Japan and the EC) for political rewards (keeping 'the West' together, with the US as its leader) was a key driver of the decisions of Nixon and his Secretary of the Treasury John Connally ${ }^{27}$. Needless to say, Europeans saw things quite differently. They had famously denounced the 'exorbitant privilege' that Bretton Woods granted to the US which could after all print and spend dollars that were supposed to be 'as good as gold' - and lamented the world-scale inflationary effects of Washington's fiscal indiscipline and military adventures.

What were the long-term goals of Nixon's unilateral way out of the dilemma - i.e. his eponymous 'shock' of 1971? According to Sargent, US policymakers did not see beyond Bretton Woods. What they aimed at was provoking a crisis within the system that could lead to a devaluation of the dollar they thought would benefit the American economy, but they miscalculated the ripple effects of their move. A manifest neoliberal agenda, proposing to give away the control of national governments over interest rates in order to unfetter financial

\footnotetext{
${ }^{25}$ See for instance Francis J. Gavin, Gold, Dollars, and Power: The Politics of International Monetary Relations, 1958-1971, (Chapel Hill, NC: University of North Carolina Press, 2004); Duccio Basosi, Il governo del dollaro. Interdipendenza economica e potere statunitense negli anni di Richard Nixon (1969-1973), (Florence: Edizioni Polistampa, 2006).

${ }^{26}$ On these aspects, see especially Barry J. Eichengreen, Exorbitant Privilege: The Rise and Fall of the Dollar and the Future of the International Monetary System, (New York-Oxford, Oxford University Press, 2011).

${ }^{27}$ This point is emphasized by Judith Stein, Pivotal Decade: How the United States Traded Factories for Finance in the Seventies, (New Haven-London, Yale University Press, 2010).
} 
markets, would emerge only later, with Connally's successor George Schultz, and would not go unchallenged within the administration ${ }^{28}$.

While there is a prevailing consensus on the need to balance 'intentionalist' and 'structuralist' explanations of the end of Bretton Woods, the debate is likely to last with works that present the choices of the Nixon administration as coherently and deliberately instrumental to the subsequent explosion of global finance ${ }^{29}$. What is remarkable, at any rate, is how brief and unsteady the much-sought devaluation-boosted economic recovery was for the US. The road to a radical revision of economic paradigms was then slow and tortuous. Alternative options were proposed and experimented, and it was only some ten years later, after the 1979 'Volcker Shock' and the embrace of a new policy of sky-high interest rates, that a new system fully emerged.

Part of the explanation for the sluggish economic growth and high inflation of the 1970s lies of course with the global increase in the price of raw materials, whose most important manifestation was the 1973 'Oil Shock', and in its entwinement with the devaluation of the dollar. The story of the dramatic hike in oil prices is in fact composed of many stories. A recent edited volume on the 1973 crisis and its economic legacy features chapters that deal with policymakers and corporations, cooperation among oil producers and among oil consumers, 'petrodollars' and transnational finance, the 'greening' of US consumer culture and the USSR's peculiar experience as an oil exporter ${ }^{30}$.

The causes and dynamics of the dramatic hike in oil prices interest us here less than the ways they affected American hegemony and the responses they elicited from Washington's policymakers. Once again, multiple readings are possible. The oil crisis unfolded in parallel with the Arab-Israeli war of October 1973, whose outcome transformed Cold War equilibria in the Middle East ${ }^{31}$. At the same time, the war and the energy crisis offered new subjects of contention between the US and Western Europe. After the heated arguments over war supplies to Israel and the OAPEC selective oil embargo, energy policy was construed as yet another 'test' for the Atlantic Alliance, following the fiasco of Kissinger's much-debated 'Year of Europe' initiative. It is in this light that most historians have analysed the Secretary of State's move of organizing an energy conference in Washington D.C. in February 1974, with

\footnotetext{
${ }^{28}$ Sargent, A Superpower Transformed, 108-130.

${ }^{29}$ See Riccardo Parboni, The Dollar and Its Rivals: Recession, Inflation and International Finance, (London: Verso, 1981) for an early theorisation of this argument; and the discussion in Daniel Sargent, "The Cold War and the international political economy in the 1970s", Cold War History, 13:3 (2013), 393-425.

${ }^{30}$ Elisabetta Bini, Giuliano Garavini and Federico Romero, Oil Shock: The 1973 Crisis and its Economic Legacy, (London: I.B. Tauris, 2016).

31 See, for one, Hanimäki, The Flawed Architect, 302-332.
} 
participation limited to thirteen major oil consuming countries. Historians of European integration, in particular, have seen this as a - rather successful - move to divide what by then looked as an increasingly united EC front. In trying to build a consumers' cartel (just the sort of confrontational response to oil producing countries the EC Nine wanted to avoid), the conference re-stated both the need for western cooperation in the face of the new challenges, and the leading role of the US: The Europeans had little alternative but to follow suit (with the sole exception of France) $)^{32}$.

1974 is therefore seen as a turning point towards a renewed (and partially transformed) Western cooperation - a trend that would only be confirmed by an extraordinarily rapid series of changes of leadership in Great Britain, West Germany and France. In the space of a few months, from March to May, Edward Heath, Willy Brandt and Georges Pompidou, the protagonists of the transatlantic quarrels of the early years of the decade, were replaced by successors - Harold Wilson, Helmut Schmidt, Valéry Giscard d'Estaing - who distinguished themselves for a pronounced Atlanticist inclination. Exit the controversial Nixon too, Gerald Ford would then preside over a revitalisation of transatlantic relations - 'The real years of Europe', as Piers Ludlow has defined them ${ }^{33}$.

American historians generally recognise the importance of this shift, but their interpretations of the energy crisis tend to stress different aspects. Meg Jacobs has recently evoked the domestic effects of the 'panic at the pump' of the 1970s. The predicament of Washington's longstanding energy self-sufficiency polarised American politics and contributed to the emergence of an influential market-oriented and pro-deregulation group within the Republican Party ${ }^{34}$. Others, focusing on the international dimension of the crisis, have de-emphasised the results of the Washington conference and the importance of the related transatlantic quarrels, highlighting instead Kissinger's effort to engage with the increasingly vocal coalition of oil producing and developing countries. The Secretary of State participated in the April 1974 special session of the UN General Assembly on raw materials and development, as well as in the 1976 Nairobi Conference of the United Nations Conference on Trade and Development (UNCTAD), and devised plans to respond to the Third World demands for a New International Economic Order

\footnotetext{
${ }^{32}$ Daniel Mockli, European Foreign Policy during the Cold War: Heath, Brandt, Pompidou and The Dream of Political Unity, (London: I.B. Tauris, 2009); Aurélie Gfeller, Building a European Identity: France, the United States, and the Oil Shock, 1973-1974, (New York-Oxford: Berghahn Books, 2012); Henning Turk, 'The Oil Crisis of 1973 as a Challenge to Multilateral Energy Cooperation among Western Industrialized Countries', Historical Social Research 39, 4, (2014), 209-230.

${ }^{33}$ Möckli, European Foreign Policy, 301-352; N. Piers Ludlow, 'The Real Years of Europe?: U.S.-West European Relations during the Ford Administration', Journal of Cold War Studies, 15, 3 (2013), 136-161.

${ }^{34}$ Meg Jacobs, Panic at the Pump: The Energy Crisis and the Transformation of American Politics in the 1970s, (New York: Hill and Wang, 2016).
} 
(NIEO). While this has led some to speak of a 'baptism in Third World politics'35 and even of an interdependence-conscious 'Southern strategy' of Kissinger ${ }^{36}$, the paltry results and adversarial motives of these initiatives can hardly be disputed.

Rather than showcasing consistent efforts at reaching out to Third World demands, the US involvement in UN General Assembly politics is mostly remembered for the brief but flamboyant tenure of Ambassador Daniel Patrick Moynihan, and for the latter's belligerent interpretation of what was emerging as a rising idea, namely the centrality of human rights. Appointed in June 1975, Moynihan immediately put himself on a collision course with the Third World-dominated General Assembly by rejecting its economic initiatives and vigorously calling out its members on their human rights record. As Barbara Keys succinctly put it, 'In essence, he responded to the developing world's clamorous calls for a redistribution of wealth by saying: no, have human rights instead'37.

Historical research on human rights is a burgeoning field. Its protagonists frequently point out just how recent a development this is - so much so that fifteen or twenty years ago the field did not even exist as such ${ }^{38}$. While many works can be credited for spearheading this surge of interest $^{39}$, it is largely due to Samuel Moyn's path-breaking The Last Utopia, published in 2010, that the 1970 s are central to this debate ${ }^{40}$. According to Moyn, it was only during that decade that a global human rights movement really took off and that human rights became both a universal language to voice aspirations of freedom and emancipation, and the basic standard against which to measure the states' conduct vis-à-vis their citizens. Previous articulations (most notably, the 1948 Universal Declaration of Human Rights) did not leave significant traces, obscured as they were by the Cold War confrontation and the postwar confidence in the state as the crucial agent for granting collective emancipation, economic development and social welfare. In the 1970s, however, the conception that held rights as universal, attached to

\footnotetext{
35 Stein, Pivotal Decade, 90.

${ }^{36}$ Sargent, A Superpower Transformed, 175-182.

${ }^{37}$ Barbara J. Keys. Reclaiming American Virtue (Cambridge, MA-London: Harvard University Press, 2014 ), 218.

${ }^{38}$ Samuel Moyn, 'Substance, Scale, and Salience: The Recent Historiography of Human Rights', The Annual Review of Law and Social Science, 8 (2012), 123-40; Mark Philip Bradley, 'American Vernaculars: The United States and the Global Human Rights Imagination', Diplomatic History, 38, 1 (2014), 1-21.

${ }^{39}$ Most notably Lynn A. Hunt, Inventing Human Rights: A history (New York-London: W.W. Norton \& Company, 2007).

${ }^{40}$ Samuel Moyn, The Last Utopia: Human Rights in History, (Cambridge, MA, and London: The Belknap Press of Harvard University Press, 2010). Moyn's approach does not go undisputed. For the purposes of this article, however, we shall not dwell on the rich debate on alternative periodisations and interpretations of human rights history. See Mark Philip Bradley, The World Reimagined: Americans and Human Rights in the Twentieth Century (New York: Cambridge University Press, 2016); Stefan-Ludwig Hoffmann, 'Human Rights and History', Past \& Present, 232, 1 (2016): 279-310. In the same issue, see also the responses by Samuel Moyn ('The End of Human Rights History', 307-322) and Lynn A. Hunt ('The Long and the Short of the History of Human Rights', 323-331).
} 
the individual, and potentially threatened by state power, gained ground and imposed itself as a new language of mobilisation - largely, Moyn argues, as a result of the exhaustion of previous revolutionary models linked to socialism, 'self-determination', or anticolonial nationalism.

Following a similar direction, many works have focused on case studies that point to the 1970 s as the moment of a crucial breakthrough of human rights discourses and activism ${ }^{41}$. In the East-West arena, many have seen the insertion of human rights provisions in the famous 'Third Basket' of the Final Act of the 1975 Helsinki Conference on Security and Cooperation in Europe (CSCE) as crucial to empowering dissidents in the Soviet bloc (and thus possibly to the end of the Cold War itself $)^{42}$. In a different context, the establishment of a series of rightwing dictatorships in South America, beginning in the mid-1960s and then continuing throughout the following decade (with the 1973 Chilean coup as a dramatic watershed), provided new focus for human rights talk and activism both within the affected countries and abroad, among the global network of NGOs and solidarity movements ${ }^{43}$. One of these organizations, the London-based Amnesty International, rapidly surged to a global fame that was sanctioned by the awarding of the 1977 Nobel Prize for Peace ${ }^{44}$. While far from the foreign policy agenda of the Nixon and Ford administrations, different brands of human rights discourses began to gain currency in US politics too. Barbara Keys has analysed the ties that link this development to the legacy of the Vietnam War. In her interpretation, embracing human rights became a way to move beyond the war trauma and construct a new narrative of US foreign policy. It is in this light that she has examined both the relaunch of an anti-totalitarian (and anti-détente) discourse by conservative Democrats à la Henry 'Scoop' Jackson and the humanitarian activism of liberals such as Donald Fraser, which both came to epitomise a more assertive role of the Congress in foreign policy matters ${ }^{45}$. In 1977, most importantly, human rights were announced as a central concern of American foreign policy by President Jimmy Carter. Carter's record in this domain would remain mixed at best, marred as it was by major inconsistencies (besides the intractable issues of détente and US-China relations, his friendly

\footnotetext{
41 For an overview, see Jan Eckel and Samuel Moyn (eds.), The Breakthrough: Human Rights in the 1970s (Philadelphia, PA: University of Pennsylvania Press, 2014).

${ }^{42}$ See Daniel C. Thomas, The Helsinki Effect: International Norms, Human Rights, and the Demise of Communism (Princeton, N.J.: Princeton University Press, 2001); Sarah B. Snyder, Human Rights Activism and the End of the Cold War: A Transnational History of the Helsinki Network (New York: Cambridge University Press, 2011).

${ }^{43}$ See William M. Schmidli, The Fate of Freedom Elsewhere: Human Rights and US Cold War Policy toward Argentina (Ithaca, NY: Cornell University Press, 2013); Jessica Stites Mor (ed.), Human Rights and Transnational Solidarity in Cold War Latin America (Madison, WI: The University of Wisconsin Press, 2013).

${ }^{44}$ See Tom Buchanan, "The truth will set you free": The making of Amnesty International', Journal of Contemporary History 37, 4 (2002): 575-597; Stephen Hopgood, Keepers of the Flame: Understanding Amnesty International (Ithaca, NY: Cornell University Press, 2013).

${ }^{45}$ Keys, Reclaiming American Virtue.
} 
approach to the Shah's Iran inevitably came under the spotlight, all the more so after the December 1978 revolution). This was of course not the first instance in which the inherently uneasy coexistence between the advocacy of universal rights, national interest, and the principle of national sovereignty became apparent, but it represented nonetheless a clear manifestation of dilemmas that would become ever more relevant in the following decades, with the articulation of the doctrines of 'humanitarian interventionism' and the 'Responsibility to protect'.

The importance of this reinterpretation of rights as pertaining to the individual beyond any notion of society or political community cannot be overestimated. Along with its implications for international relations, it reflected a shift in perceptions and expectations about associated life and politics, and as such figures prominently in historical research well beyond works of international history (the first reference is of course Daniel Rodger's Age of Fracture, with its subtle analysis, pursued in terms of intellectual history, of the disaggregation of previously solid notions of society and collectivity in America) ${ }^{46}$. In a similar vein, Tim Borstelmann has spoken of a 'pattern' that was 'taking shape around the world, one emphasising human rights and selfdetermination, on the one hand, and the declining legitimacy of socialism and government management of the economies, on the other' ${ }^{37}$.

Considerations on the Soviet Union would go beyond the scope of this article. Yet it would be impossible not to point at an entanglement in the destinies of the two superpowers that transcends diplomatic confrontations and efforts to stabilise a fissuring global condominium. Vladislav Zubok has suggested to examine 1970s détente 'as part of the global history at the moment of its epochal transition: when the rise of Soviet communism stopped, and the collapse of the Soviet bloc began'48. This conclusion, whose validity could be extended to the whole of the communist movement ${ }^{49}$, has profound implications, which still have not been fathomed in depth $^{50}$. A careful study of the multiple links between the Soviet decline and the transformation of the Western system would instead be crucial, and could also shed new, retrospective light on one of the central questions of any global interpretation of the $20^{\text {th }}$ Century, that of the

\footnotetext{
${ }^{46}$ Rodgers, Age of Fracture.

${ }^{47}$ Borstelmann, The 1970s, 175. Samuel Moyn has also recently emphasised the link between human rights and the global political and economic transformations that began in the 1970s: see his Not Enough: Human Rights in an Unequal World (Cambridge, MA: The Belknap Press of of Harvard University Press, 2018).

${ }^{48}$ V. M. Zubok, 'The Soviet Union and Détente of the 1970s', Cold War History, 8, 4 (2008), 428. See also Idem, A Failed Empire. The Soviet Union in the Cold War from Stalin to Gorbachev, The University of North Carolina Press, Chapel Hill 2009.

${ }^{49}$ See Silvio Pons, The Global Revolution: A History of International Communism 1917-1991 (Oxford-New York, Oxford Univesity Press, 2014).

${ }^{50}$ See the perceptive remarks of Romero, 'Cold War Historiography at the Crossroads', 701-702.
} 
relationship between the 'socialist challenge' and the 'reform' of capitalism. Examining the disarticulation of the postwar equilibria might provide the proverbial inverted telescope through which to look at the controversies of the past century and possibly move forward to new conceptualisations ${ }^{51}$.

\section{Western European Trajectories}

Welfare capitalism declined in the US during the 1970s, but it was in Western Europe that its drama unfolded most vividly. Periodisations of postwar European history that hinge on the 1970s have largely displaced previous ones that focused on the $1960 \mathrm{~s}^{52}$. To historians as well as to non-specialists, the origins of Europe's troubled present seem to lie more with the uncertain age of the global shocks than with the optimistic thrust that animated both reformists and professed revolutionaries in the years that preceded $\mathrm{it}^{53}$. At closer look, however, constructing a unified Western European narrative of the decade requires bridging different, and often diverging experiences and interpretations. In her introduction to a recent special issue of the journal Geschichte und Gesellschaft, Sonja Levsen has pointed at this problem by discussing historiography on the 1970s in Britain, France and Germany. Narratives of national economic decline and breakup of social consensus still dominate the panorama in the UK, but the story of the decade is more often told as one of political mobilisation and social modernisation in France, or of involvement in broader, 'structural' transformations in Germany ${ }^{54}$. And the focus is different still in other countries: Transition to democracy in Greece, Portugal and Spain, crisis and political violence in Italy (where the media mostly refer

\footnotetext{
${ }^{51}$ For an erudite, passionate, and highly personalised approach to these 'controversies of the past century' see Tony Judt, 'The Last Romantic', The New York Review of Books, 20 November 2003; Eric J. Hobsbawm, 'After the Cold War', London Review of Books, 34, 8, 26 April 2012.

${ }^{52}$ This also because, as Martin Conway ironically remarked, 'to put it at its most simplistic, much of that which we think happened in the 1960s in fact occurred in the 1970s' (Martin Conway, 'The Rise and Fall of Western Europe's Democratic Age', Contemporary European History, 13, 1 (2004), pp. 67-88 (here: 70).

${ }^{53}$ See, for one, Dan Stone, Goodbye to All That?: The Story of Europe Since 1945 (Oxford-New York, Oxford University Press, 2014), 120-123 and 161-195.

${ }^{54}$ Sonja Levsen, 'Einführung: Die 1970er Jahre in Westeuropa-un dialogue manqué', in Geschichte und Gesellschaft, 42, 2 (2016), 213-242. Levsen interestingly points out how periodisations and definitions of this period vary accordingly, especially in the French case: see Geneviève Dreyfus-Armand et al., Les années 68: le temps de la contestation, (Bruxelles: Complexe, 2000) ; Jean-François Sirinelli, Les vingt décisives, 1965-1985: le passé proche de notre avenir, (Paris: Fayard, 2007); Jean Vigreux, Croissance et contestations.(1958-1981), (Paris: Seuil, 2014).
} 
to the 1970 s as the 'Years of Lead'), modernisation and reform in Austria - to mention just a few ${ }^{55}$.

To weave these and other threads into a single fabric, one can begin by looking at the prime locus of intra-European cooperation, the European Community ${ }^{56}$. Long viewed as a phase of 'Eurosclerosis' during which the EC member states, hard hit by the economic crisis, failed to live up to their stated goal of building an 'ever closer union', the history of European integration during the 1970s has been largely detached from such teleological standards and reconsidered as one of adaptation and change whose outcomes would be crucial to the ensuing evolution of the Community ${ }^{57}$. A testament to this reappraisal is Wilfried Loth's recent survey study Building Europe, which features two chapters on the decade, respectively titled 'Expansion and New Perspectives, 1969-1975' and 'Consolidation, 1976-1984'58. In an even clearer-cut rejection of old paradigms, Claudia Hiepel has proposed to embed the history of $1970 \mathrm{~s}$ European integration into that of globalisation, concluding (with perhaps a hint of exaggeration) that 'on the whole, the EC underwent a boost that raises the question whether this was part of a strategy of regionalisation in response to globalisation, ${ }^{59}$.

Interdependence was not a recent discovery for European states. Lacking self-sufficient internal markets, dependent on imports of energy and raw materials, and relying on the US security backing, they could be 'rescued' after World War II only in a context of regional (and transatlantic) integration ${ }^{60}$. Moreover, in spite of the momentous advances of decolonisation,

\footnotetext{
${ }^{55}$ Mario Del Pero et al., Democrazie. L'Europa Meridionale e la fine delle dittature (Milan: Le Monnier, 2010); Agostino Giovagnoli et al (eds.), L'Italia repubblicana nella crisi degli anni Settanta, 4 volumes (Soveria Mannelli: Rubbettino, 2003); Marc Lazar and Marie Anne Matard-Bonucci (eds.) Il libro degli anni di piombo: storia e memoria del terrorismo italiano (Milan: Rizzoli, 2010); Günther Bischof and Anton Pelinka, (eds.), The Kreisky Era in Austria (Piscataway, N.J., Transaction publishers, 1994).

${ }^{56}$ Kiran Klaus Patel has convincingly argued the need to 'provincialise' our understanding of the European Community/Union as the quintessential example of international cooperation, but at the same time recognised the EC/EU 'synecdochic quality', the way it turned into the 'symbolic core of all attempts of European co-operation'. Kiran Klaus Patel, 'Provincialising European Union: Co-operation and integration in Europe in a historical perspective', Contemporary European History, 22, 4 (2013), 649-673.

${ }^{57}$ For an overview of this debate, see the special issue 'Eurosclérose ou européanisation? L'intégration européenne dans les années 1970', L'Europe en formation, 353-354, 3-4 (2009). More broadly, see Antonio Varsori (ed.), Alle origini del presente: l'Europa occidentale nella crisi degli anni Settanta (Milan: FrancoAngeli, 2007); Antonio Varsori and Guia Migani, Europe in the International Arena during the 1970s. Entering a Different World, (Brussels: Peter Lang, 2011). For a criticism of the 'progressive narrative' of the European construction see Mark Gilbert, "Narrating the Process: Questioning the Progressive Story of European Integration", Journal of Common Market Studies, 46, 3 (2008), 641-662.

${ }^{58}$ Wilfried Loth, Building Europe: A History of European Unification, (Berlin-Boston: De Gruyter, 2015).

${ }^{59}$ Claudia Hiepel, 'Introduction', in Claudia Hiepel (ed.), Europe in a Globalising World. Global Challenges and European Responses in the 'Long'1970s, (Baden-Baden, Nomos, 2014), 12.

${ }^{60}$ Alan Milward (with the assistance of George Brennan and Federico Romero), The European Rescue of the Nation State, (London: Routledge, 2000). For a review of the huge literature on European integration and transatlantic relations, see Alessandra Bitumi, 'Rethinking the Historiography of Transatlantic Relations in the Cold War Years: The United States, Europe and the Process of European Integration', in Maurizio Vaudagna (ed.),
} 
relations with former colonies still marked profoundly their economies and societies. Nevertheless, the end of the postwar equilibria brought with itself a transformation of both the context and goals of intra-European cooperation. Antonio Varsori has stressed the impact of the 'global 1968': In accordance with the widespread emergence of new political and social orientations, the decades-long preponderance of centrist and conservative governments gave way to a more diverse panorama and a growing role of social democratic parties, which tried to answer to new public demands and extended to the EC arena their programmes of reform ${ }^{61}$. Not only was the scope of European cooperation expanded, with the first plans and experiments for common strategies in matters of monetary and foreign policy, education and welfare; the Community itself gained political and economic clout with the 1973 accession of Great Britain, Ireland and Denmark. Crucially, Community initiatives grew autonomous from transatlantic priorities, so much so that former opponents of Western cooperation (such as the Italian Communist Party) began to distinguish 'Europeanism' from 'Atlanticism'62. Cracks and hesitations in the international leadership of the US reinforced this tendency, as did unilateral responses from Washington. The acceleration of European monetary cooperation during the turbulent post-Bretton Woods years, first with the 'Snake in the tunnel' and then with the more stringent European monetary system (EMS), is a good case in point ${ }^{63}$.

It was however détente that immediately captured the attention of Cold War historians, who recognised it as the single development that did the most to lay bare the changing nature of bipolarism and transatlantic relations. Focusing especially on the German Ostpolitik, they identified a specific European approach to East-West policies: In devising long-term schemes for overcoming the division of Europe, the protagonists of Ostpolitik were in fact operating a détournement of the conservative discourse and goals that lied at the core of the superpowers' détente - this, of course, to the frequent chagrin of US policymakers ${ }^{64}$. While carefully, and sometimes suspiciously monitored by the European partners, Ostpolitik was soon embedded into a European framework of East-West negotiations, also as a result of the German government's own efforts to reassure its allies. This approach was crucial to the so-called

\footnotetext{
Modern European-American Relations in the Transatlantic Space: Recent Trends in History Writings, (Turin: Otto, 2015), 71-95.

${ }^{61}$ Antonio Varsori, 'The European Construction in the 1970s. The Great Divide', in Varsori and Migani (eds.), Europe in the International Arena during the 1970s, 27-39.

${ }^{6}$ See Silvio Pons, Berlinguer e la fine del comunismo, (Turin: Einaudi, 2006).

${ }^{63}$ Emmanuel Mourlon-Druol, A Europe Made of Money: The Emergence of the European Monetary System, (Ithaca, NY: Cornell University Press, 2012).

${ }^{64}$ For an introduction, see American Détente and German Ostpolitik, 1969 - 1972, GHI Bulletin Supplement, 1 (2004); Carole Fink and Bernd Schaefer (eds.), Ostpolitik, 1969-1974. European and Global Responses (Cambridge: Cambridge University Press, 2009); Wilfried Loth, and Georges-Henri Soutou (eds.), The Making of Détente: Eastern Europe and Western Europe in the Cold War, 1965-75, (London-New York: Routledge, 2010).
} 
Helsinki process and to the attainment of a unified position of the EC at the $1975 \mathrm{CSCE}^{65}$. In both its 'conservative' and 'dynamic' versions, détente contributed - in most cases, against the will of its proponents - to the erosion of both the ideological foundations and the 'disciplinary capacity of bipolarism', as Mario Del Pero has defined it. As a consequence, it strengthened the role of Europe 'as a sort of surrogate disciplinary tool' - as it happened for instance during the turbulent democratic transition that followed the overthrow of Portugal's authoritarian regime in $1974^{66}$.

The EC and national governments were not the only agents of this development. A growing literature is focusing for instance on social democratic parties and political networks, which played a key role in both détente and the Iberian democratic transitions, as the bearers of a specific interpretation of 'European identity' ${ }^{67}$ and the protagonists of a 'party diplomacy' that overlapped with- and complemented that of the states. Especially important was their support to fellow socialists in Portugal and Spain, first after the fall of the dictatorships and then during their application for EC membership ${ }^{68}$. Traditionally interpreted within Cold War frameworks (supporting the socialists meant first and foremost toppling communist influence in the region) and as a success story of solidarity and democratic acculturation to 'European values', this link between social democratic parties in the prosperous core of Europe and their Southern European counterparts activated learning processes and circulations of policy strategies that may assume new meanings and implications in the light of the recent crisis of the Eurozone, when asymmetrical relations between a 'normative' European centre and distressed peripheries resurfaced, this time in a far more contentious setting ${ }^{69}$.

\footnotetext{
${ }^{65}$ Andreas Wenger, Vojtech Mastny and Christian Neuenlist (eds.), Origins of the European Security System: the Helsinki Process Revisited, 1965-75. (London: Routledge, 2008); Oliver Bange and Gottfried Niedhart (eds.), Helsinki 1975 and the Transformation of Europe, (New York: Berghahn, 2008); Angela Romano, From Détente in Europe to European Détente. How the West Shaped the Helsinki CSCE (Brussels: Peter Lang, 2009).

${ }^{66}$ Mario Del Pero, "'Which Chile, Allende?" Henry Kissinger and the Portuguese revolution', Cold War History, 11, 1 (2011), 1-33.

${ }^{67}$ On the role played by the Southern enlargement in shaping the notion of a 'political identity' of the EC based on democratic values, see Emma De Angelis and Eirini Karamouzi, 'Enlargement and the Historical Origins of the European Community's Democratic Identity, 1961-1978', Contemporary European History, 25,3 (2016), 439-458.

${ }^{68}$ Del Pero et al., Democrazie; Antonio Muñoz Sánchez, El amigo alemán. El SPD y el PSOE de la dictadura a la democracia (Barcelona: RBA Libros, 2012); David Castaño, "A practical test in the détente": International support for the Socialist Party in the Portuguese Revolution (1974-1975)', Cold War History, 15, 1 (2015), 1-26; Christian Salm, Transnational Socialist Networks in the 1970s: European Community Development Aid and Southern Enlargement, (Basingstoke: Palgrave MacMillan, 2016).

${ }^{69}$ Focusing on a partly different context, Eirini Karamouzi, Greece, the EEC and the Cold War, 1974-1979: The Second Enlargement, (Basingstoke: Palgrave Macmillan, 2014) makes the case for putting into historical perspective the debates on Greece and European integration that followed the post-2010 crisis, spotlighting especially the accession negotiations that took place in the second half of the 1970s.
} 
Other formal and informal networks, alongside those of social democracy, acted as agents of 'Europeanisation'; a process that received further boosts from internal developments such as the first direct elections of the European Parliament in $1979^{70}$. A distinct European voice was to be heard also on North-South issues, as both EC members and neutral countries such as Sweden and Austria displayed a relatively open attitude towards Third World activism and the NIEO. While this political climate brought some concrete fruits (from the setting up of an official 'Euro-Arab dialogue' to the new Lomé Convention on EC trade with ACP countries), it also left an agenda of unfulfilled promises, which was soon taken up by new networks of policy advocacy such as the Independent Commission on International Development Issues led by Willy Brandt ${ }^{71}$.

The North-South dialogue would in fact decline during the second half of the decade and then come to an end in the early 1980s, among the whimpers of ineffective summits and the bangs of a row of debt crises affecting the developing countries. This result was part of a broader trend, a twist of atmosphere that Mark Mazower has powerfully captured with a single adjective: Calls for a New International Economic Order founded on global wealth redistribution, state intervention and economic sovereignty were being replaced by the establishment of a real new international economic order, whose lynchpin was worldwide market liberalisation ${ }^{72}$. Coalescing with the oil shock and multiple inflationary pressures, the mid-decade downturn in economic growth marked a major discontinuity in the European trajectory after the collapse of the postwar equilibria. European industrial production suffered in the face of rising costs and increased competition, and expansive responses to economic stagnation by national governments only fuelled inflation. With national social corporatist compacts under strain, on the one hand, and confidence in macroeconomic Keynesian remedies undermined, on the other, reformist enthusiasms ebbed and EC states gradually realigned their economic management to new priorities. Dan Stone has used the German definition of

\footnotetext{
70 Wolfram Kaiser, Brigitte Leucht, and Michael Gehler (eds.), Transnational Networks in Regional Integration: Governing Europe 1945-83, (Basingstoke: Palgrave MacMillan, 2016); Guido Thiemeyer and Jenny RaflikGrenouilleau (eds.), Les partis politiques européens face aux premières élections directes du Parlement Européen, (Baden-Baden: Nomos, 2015).

${ }^{71}$ Tor Sellström, Sweden and National Liberation in Southern Africa, vol. II, Solidarity and Assistance 1970-1994, (Uppsala: Nordiska Afrikainstitutet, 2002); Willy Brandt, Berliner Augabe, vol. 8, Über Europa hinaus. Dritte Welt und Sozialistische Internationale, ed. by Bernd Rother and Wolfgang Schmidt, (Bonn, Dietz, 2006); Elisabeth Rörlich, Kreiskys Außenpolitik. Zwischen österreicher Identität und internationalem Programm, (Göttingen: V\&R Unipress, 2009), 330-342; Giuliano Garavini, After Empires. European Integration, Decolonization, and the Challenge from the Global South 1957-1986 (Oxford: Oxford University Press, 2012).

${ }^{72}$ Mark Mazower, Governing the World: The History of an Idea, 1815 to the Present, (New York: Penguin Books, 2012), 343-377.
} 
Tendenzwende (change in tendency) to sum up this process ${ }^{73}$. At the same time, however, recent research mostly describes the relation between the 'old' and the 'new' order as a dialectical, rather than antinomical one, and focuses on the contrasting pushes out of which a transformed equilibrium emerged. Laurent Warlouzet, in particular, has convincingly argued that 'socially oriented', 'neomercantilist' and 'market-oriented' responses to the post-1973 economic shocks competed with one another in Europe, so much so that describing an inexorable path towards a 'neoliberal Europe' would be misleading ${ }^{74}$.

\section{New Global Rules}

That a transformation did happen, however, nobody disputes. Understanding its nature, development and implications, while at the same time shunning simplistic definitions, represents a compelling challenge for historical research. Coherently with the key hypotheses of this review, it is possible to point at a growing literature that singles out transatlantic responses to a number of 'crises' of the late 1970s as a key laboratory of what we may call, for lack of better definition, the 'age of globalisation'. The post-1974 relaunch of US-European cooperation was part and parcel of this process. The perception of a multifaceted crisis of the 'West' (spanning the ostensible decline of the US and consolidation of the Soviet bloc, the increasing assertiveness of the Third World, economic troubles, domestic tensions and political instability in several countries) spurred instances of ad hoc collaboration among the major powers as well as the creation of new tools of global and regional governance, such as the G6/G7 summits and the European Council ${ }^{75}$.

As Western prosperity appeared to be in question for the first time since the postwar reconstruction, economics became an increasingly crucial feature of diplomacy. Many have focused on the 1976 British 'IMF crisis' as a key turning point. In the face of a major balance

\footnotetext{
${ }^{73}$ Stone, Goodbye to All That?, 162-163.

${ }^{74}$ Laurent Warlouzet, Governing Europe in a Globalizing World: Neoliberalism and its Alternatives After the 1973 Oil Crisis, (New York-London: Routledge, 2017). See also Andreas Wirsching (ed.), "The 1970s and the 1980s as a Turning Point in European History? A Forum with Göran Therborn, Geoff Eley, Hartmut Kaelble, Philippe Chassaigne", Journal of Modern European History, 9, 1 (2011), 8-26.

${ }^{75}$ Emmanuel Mourlon-Druol and Federico Romero (eds.), International Summitry and Global Governance. The Rise of the G7 and the European Council, 1974-1991, (London-New York: Routledge 2014); Kristina Spohr and David Reynolds (eds.), Transcending the Cold War: Summits, Statecraft, and the Dissolution of Bipolarity in Europe, 1970-1990, (Oxford: Oxford University Press, 2016). The Trilateral Commission also emerged in this context as an avenue for informal élite diplomacy, with a focus on promoting coordinated responses from the US, Europe and Japan to the challenge of 'interdependence'. See Dino Knudsen, The Trilateral Commission and Global Governance: Informal Elite Diplomacy, 1972-82, (London-New York: Routledge, 2016).
} 
of payments deficit, a falling sterling, and double-digit inflation, the British Labour government recurred to an IMF loan, which was granted on condition that a fiscal consolidation programme be enacted. The actual impact of the programme is debated, but the episode, which shocked and divided the British Left (among whose ranks many advocated an 'Alternative Economic Strategy' based on planning and import controls), has been often depicted as both the death knell for national Keynesianism and a foreshadowing of the subsequent globalisation of IMF interventions in the Third World and the imposition of economic plans informed by the socalled 'Washington Consensus'"76.

In the same months, 'traditional' and 'economic' diplomacy combined in the Western response to another 'crisis', this time in Italy. The country's economic condition was sharply deteriorating and pressures were growing for a participation in government of the ever-stronger Communist Party, which was by then pursuing a moderate domestic strategy and leading a transnational movement for a reformed communism, the so-called Eurocommunism ${ }^{77}$. Construed, once again, as a test for the cohesiveness of the West, the Italian situation was monitored in the context of quadripartite (US-German-British-French) meetings on the 'destabilisation of NATO's Southern flank' and figured eminently in the first G6-G7 meetings. At the Puerto Rico G7 meeting of June 1976, held just a few days after a general election in Italy, economic conditionality emerged again as a tool to bind the Italian government to a stabilisation programme and to complement the Western powers' 'moral suasion' against any accession to power by the communists ${ }^{78}$.

The case of Eurocommunism is especially illustrative of the melding of Cold War and 'global-economic' logics in the phase of transition of the late 1970s. Long seen mainly as an example of the limits and contradictions of détente, the rise and fall of Western 'reform communism' is being reconsidered in the light of broader political-economic developments, which involved not only Communist parties, but European politics at large ${ }^{79}$. Once again, the

\footnotetext{
${ }^{76}$ Harold James, International Monetary Cooperation since Bretton Woods (Oxford-New York: Oxford University Press; Washington, D.C.: International Monetary Fund, 1996), 279-282 and 322-335; Kevin Hickson, The IMF Crisis of 1976 and British Politics, (London: I.B. Tauris, 2005); Mazower, Governing the World, 343-359.

${ }^{77}$ See Silvio Pons, 'The Rise and Fall of Eurocommunism', in Melvyn Leffler and Odd Arne Westad (eds.), The Cambridge History of the Cold War, vol. III, (Cambridge- New York: Cambridge University Press, 2010), 45-65.

78 Duccio Basosi and Giovanni Bernardini, 'The Puerto Rico Summit and the End of Eurocommunism', in Leopoldo Nuti (ed.), The Crisis of Détente in Europe: From Helsinki to Gorbachev: 1975-1985, (New YorkLondon: Routledge, 2008), 256-267; Lucrezia Cominelli, L'Italia sotto tutela. Stati Uniti, Europa e crisi italiana degli anni Settanta, (Milan: Le Monnier, 2014).

79 Basosi and Bernardini, 'The Puerto Rico Summit'; Michele Di Donato, 'The Cold War and Socialist Identity. The Socialist International and the Italian "Communist Question" in the 1970s', Contemporary European History, 24, 2 (2015), 193-211. Another example is that of the French Union de la gauche: see Frédéric Heurtebize, Le péril rouge. Washington face à l'eurocommunisme, (Paris: PUF, 2014); Idem, 'Eurocommunism and the Contradictions of Superpower Détente', Diplomatic History, 41, 4 (2017), 747-771. For a comparative approach,
} 
1970s represented a watershed. In the EC, the 1979 agreement on the creation of the EMS marked, in the words of Emmanuel Mourlon-Druol, 'the consecration of a new economic and monetary consensus, largely influenced by stability-oriented economic policies aimed at fighting inflation' ${ }^{80}$. The centrality of Germany and the 'German model' in these developments, which emerges for instance from Kristina Spohr's work on Helmut Schmidt, has led some to claim that the Federal Republic's steadfast opposition to the interventionist economic strategies of the Left played a crucial role in the "neoliberal resolution of the 1970s crisis ${ }^{81}$.

While there is reason to criticise this rather cavalier use of the category of 'neoliberalism', it remains nonetheless crucial to go beyond the ingrained image of the post-1970s economic shifts as the mere result of a revolution, or counterrevolution, promoted by Margaret Thatcher and Ronald Reagan. Recent scholarship on US economic and foreign relations history clearly shows that changes in the country's economic orientation were in fact gradual and to a large extent unforeseen (and unforeseeable). Both Daniel Sargent and Judith Stein have spotlighted Jimmy Carter's attempt, inspired by his Trilateralist philosophy, to promote a strategy of 'international Keynesianism', persuading West Germany and Japan to act, together with the US, as 'locomotives' of global economic growth. It was only after the failure of this scheme, due at first to the opposition of the two hypothetical partners, and then to the devastating impact of the second oil shock triggered by the Iranian Revolution, that the administration turned to prioritising fiscal stabilisation and the fight against inflation, thus paving the way for Paul Volcker FED's momentous intervention of October 1979. After the election of Ronald Reagan, the policy of tight money, prohibitive interest rates and hyper-strong dollar was confirmed and complemented by an agenda of markets deregulation and tax cuts (as well as massive military expenses). The consequences of these changes were dramatic not only for the US (several studies have analysed how the interaction between monetary policy and the progressive deregulation of domestic and international finance decisively contributed to the decline of manufacturing industry and to the financialisation of American economy), but globally, as the new conditions led to a massive inflow of capital towards the US that radically altered the country's position in the global political economy. While Europeans lamented the deflationary bias of the new environment and an abnormal situation in which the rest of the world was

\footnotetext{
see Sotiris Rizas, The Rise of the Left in Southern Europe: Anglo-American Responses, (London: Pickering \& Chatto, 2012).

${ }^{80}$ Mourlon-Druol, A Europe Made of Money, 259. See also Michel-Pierre Chélini and Laurent Warlouzet (eds.), Calmer les prix : l'inflation en Europe dans les années 1970, (Paris : Presses de Sciences Po, 2016).

${ }^{81}$ Kristina Spohr, The Global Chancellor: Helmut Schmidt and the Reshaping of the International Order, (OxfordNew York: Oxford University Press, 2016); Julian Germann, "German "Grand Strategy" and the Rise of Neoliberalism’, International Studies Quarterly, 58 (2014), 706-716 (here: 707).
} 
practically financing the deficits of the biggest Western power, it was Third World countries, now unable to either service their foreign debt or attract capitals, who suffered most from the consequences of the new state of affairs ${ }^{82}$.

'The United States rose to power as an empire of production but by the end of the century had become an empire of consumption', Charles Maier famously remarked, noting the country's shift to a persistent situation of deficit both in the federal budget and in the current account balance ${ }^{83}$. Scholars of various disciplines have proposed different interpretations of this turn to a credit-based economy (which was accompanied by the vigorous rise of new exporting powers, most notably in East Asia). Influenced by Marxism and paradigms of macro-historical analysis rooted in the works of Fernand Braudel and Immanuel Wallerstein, Giovanni Arrighi's Long Twentieth Century exemplifies an early tendency to interpret these changes within a declinist framework. The book analysed the US turn to finance as the manifestation of a recurring pattern in the capitalist system, with finance replacing material production as the main source of accumulation as one 'hegemonic power' went downhill and another began its ascendancy ${ }^{84}$. On the opposite side, others stressed the US continuing primacy and expanding role, and saw the post-1970s changes as instrumental to the emergence of an American-led globalisation ${ }^{85}$.

With new archival sources becoming available, historians are increasingly entering a field that students of International Political Economy and World Systems Theory, as well as sociologists and political scientists, have already been exploring ${ }^{86}$. What emerges as both an overarching theme of this still hybrid literature and a fertile ground for research is the study of what can be called the 'setting of the rules': The process by which - to paraphrase Karl Polanyi, a key reference for many of these authors - norms and institutions were devised to organise and regulate a new market society and a new laissez faire. These 'rules' were then implemented on an increasingly global scale, as first Third World nationalist regimes and then the Soviet bloc

\footnotetext{
${ }^{82}$ Stein, Pivotal Decade, 154-175 and 225-270; Sargent, A Superpower Transformed, 237-250 and 273-280; Greta R. Krippner, Capitalizing on Crisis: The Political Origins of the Rise of Finance, (Cambridge, MA-London: Harvard University Press, 2011); Iwan Morgan, 'Monetary Metamorphosis: The Volcker FED and Inflation', The Journal of Policy History, 24, 4 (2012), 545-571. On Europe, see Duccio Basosi, 'The European Community and International Reaganomics, 1981-1985', in Kiran Klaus Patel and Kenneth Weisbrode (eds.), European Integration and the Atlantic Community in the 1980s, (Cambridge: Cambridge University Press, 2012), $133-153$. On the Third World, Odd Arne Westad, The Global Cold War: Third World Interventions and the Making of Our Times, (Cambridge: Cambridge University Press, 2005), 357-363; Garavini, After Empires, 241-249.

${ }^{83}$ Charles E. Maier, Among Empires: American Ascendancy and its Predecessors, (Cambridge, MA-London: Harvard University Press, 2006), 255.

${ }^{84}$ Arrighi, The Long Twentieth Century.

${ }^{85}$ See, from different perspectives, James, International Monetary Cooperation, 409-466; David Harvey, A Brief History of Neoliberalism, (Oxford-New York: Oxford University Press, 2005).

${ }^{86}$ For a review of this literature, see Sargent, 'The Cold War and the International Political Economy', 409-424.
} 
were fully integrated into the world economy. It is in a similar vein that Monica Prasad and Greta Krippner have examined 'the politics of free markets' and those of the financialisation of the economy in the US and in various European countries; or that Alasdair Roberts has discussed how governmental functions were reformed, rearranged and made consistent with the new prevalence of the market according to what he calls a new 'logic of discipline' ${ }^{87}$. In analysing the 'global rules' of a world order based on free markets, market-based democracies and human rights, James Cronin has insisted on the agency of American and British policymakers (the post-Cold War order, he has argued, 'represented the extension of what can be labeled "Atlantic Rules" to the rest of the world'). This view contrasts with Rawi Abdelal's stress on the role of continental European (and especially French) actors in creating an institutional framework in which to promote a 'managed globalisation', or mondialisation maîtrisée $e^{88}$.

At the same time, the fact that the transitions of the late 1970s also took place in a context of rekindling East-West tensions has not escaped the historians' attention. The consequences of the restructuring of the Western economic order deeply affected the Soviet bloc, aggravating the financial and economic problems of the many indebted countries and exacerbating the planned economies' difficulties in renovating their industrial base and engaging with the information technology revolution ${ }^{89}$. From a political-intellectual perspective, the crisis of détente, and especially aggressive Soviet moves such as the 1979 invasion of Afghanistan, contributed to weakening the legitimacy of 'socialism' (which to many was becoming a catchall definition for any form of state-centred economic intervention), a process that was crucial to the rise of the neoconservative movement in the US and to the decline of Welfare capitalism in Europe ${ }^{90}$. US-European tensions resurfaced too, and with them the Europeans' fear that their

\footnotetext{
${ }^{87}$ Monica Prasad, The Politics of Free Markets: The Rise of Neoliberal Economic Policies in Britain, France, Germany, and The United States (Chicago, IL: Chicago University Press, 2006); Krippner, Capitalizing on Crisis; Alasdair Roberts, The Logic of Discipline: Global Capitalism and the Architecture of Government, (Oxford-New York: Oxford University Press, 2010).

${ }^{88}$ James E. Cronin, Global Rules: America, Britain and a Disordered World (New Haven, CT: Yale University Press, 2014), 3; Rawi Abdelal, Capital Rules: The Construction of Global Finance, (Cambridge, MA-London: Harvard University Press, 2007).

${ }^{89}$ Charles E. Maier, Dissolution: The Crisis of Communism and the End of East Germany, (Princeton: Princeton University Press, 1999); Idem, 'Thirty Years After: The End of European Communism in Historical Perspective', in The Cambridge History of Communism, vol. III, Endgames? Late Communism in Global Perspective, 1968 to the Present, edited by Juliane Fürst, Silvio Pons, and Mark Selden, (Cambridge: Cambridge University Press, 2017), 581-599; Stephen Kotkin, Armageddon Averted: The Soviet Collapse, 1970-2000, (Oxford-New York: Oxford University Press, 2008); Giovanni Arrighi, 'The World Economy and the Cold War', in The Cambridge History of the Cold War, vol. III, 23-44.

${ }^{90}$ John Ehrman, The Rise of Neoconservatism: Intellectuals and International Affairs 1945-1994, (New Haven and London: Yale University Press, 1995); Del Pero, The Eccentric Realist; Justin Vaïsse, Neoconservatism: The Biography of a Movement, (Cambridge, MA, and London: The Belknap Press of Harvard University Press, 2010); Tony Judt, Postwar. A History of Europe Since 1945, (New York: Penguin Press, 2004), 535-66; Jan-Werner
} 
defence might be 'decoupled' from that of their American allies. The 'Euromissile' crisis was a major, but not isolated, catalyst for these renewed transatlantic strains: Its fractured politics, which cut across national and political divides, showed the contrast between new strategic concerns and the will to preserve intra-European détente ${ }^{91}$.

\section{Conclusion. A Turning Point for History and Historiography?}

Debates and negotiations over nuclear weapons did not just revive interstate tensions. They also reenergised transnational anti-nuclear movements, which in the early 1980s managed to bring to the streets hundreds of thousands of people in Western Europe and to mobilise many others all over the world ${ }^{92}$. Seeing nuclear weapons as a threat to the whole of humanity, these activists not only denounced nuclear rearmament strategies, but also displayed an understanding of the challenges of world politics that largely transcended Cold War divides. Opposition to nuclear weapons grew increasingly entwined with environmentalist critiques of the civilian use of atomic energy - also spurred by accidents such as the one that occurred in the atomic power station of Three Mile Island, Pennsylvania, in 1979. Global environmentalism emerged as a sizeable force during the 1970s, with the 1970 'Earth Day' celebrations or the 1972 Stockholm Conference of the UN on 'human environment' as landmark moments. Its emphasis on the undesirable consequences of industrialisation represented an indictment of the race for economic growth that was typical of the Cold War competition ${ }^{93}$.

These developments, together with others that were discussed in this article, have contributed not only to shaping the world we live in, but also to changing the way historians look at the past. In a 2013 book, Akira Iriye discussed what he saw as a 'lag between "history," on one hand, and "historiography" on the other'. Historians, he argued, had been 'falling behind

\footnotetext{
Müller, Contesting Democracy: Political Ideas in Twentieth-Century Europe, (New Haven-London: Yale University Press, 2011), 202-242.

${ }^{91}$ Leopoldo Nuti et al. (eds.), The Euromissile Crisis and the End of the Cold War, (Washington, D.C.: Woodrow Wilson Center Press, 2015); Patel, Weisbrode, European Integration and the Atlantic Community.

${ }^{92}$ Lawrence S. Wittner, The Struggle against the Bomb, vol. III, Toward Nuclear Abolition. A History of the World Nuclear Disarmament Movement, 1971 to the Present, (Stanford, CA: Stanford University Press, 2003); Benjamin Ziemann (ed.), Peace movements in Western Europe, Japan and the USA during the Cold War, (Essen: Klartext, 2008); Holger Nehring and Benjamin Ziemann, 'Do All Paths Lead to Moscow? The NATO Dual-Track Decision and the Peace Movement: A Critique, Cold War History, 12, 1 (2012), 1-24.

${ }^{93}$ For an introduction, see J.R. McNeill, "The Environment, Environmentalism, and International Society in the Long 1970s," in The Shock of the Global, 263-278; J.R. McNeill and Corinna R. Ungert (eds.), Environmental Histories of the Cold War, (Cambridge: Cambridge University Press, 2010); Andrew Tomkins, 'Grassroots Transnationalism(s): Franco-German Opposition to Nuclear Energy in the 1970s', Contemporary European History, 25, 1, (2016), 117-142.
} 
history': While 'global and transnational developments and forces were becoming increasingly evident' since the late 1960 s, so much so that the 'centrality of the nation-state [was] challenged by global, human concerns', historians 'remained wedded to their traditional perspectives and conceptualizations till toward the end of the twentieth century or the early years of the twentyfirst century ${ }^{94}$. In the same vein, he criticised periodisations of post-1945 history that hinged on the Cold War, which he believed explained 'little about non-geopolitical aspects of international relations or about transnational movements', and therefore could not capture crucial themes such as globalisation, environmentalism or human rights ${ }^{95}$. Focusing instead on the emergence of a 'transnational world', Iriye was more interested in the agency of actors of the 'global civil society' such as the international NGOs that had been mushrooming during the $1970 s^{96}$.

This approach has been embraced by many in the last two decades, and global and transnational history are now so popular that, as David Armitage provocatively put it, 'if you are not doing an explicitly transnational, international or global project, you now have to explain why you are not. ... The hegemony of national historiography is over ${ }^{97}$. This development has been recounted and debated in countless reviews and surveys, which have also spelled out the distinction between global and transnational approaches, and between global history and the history of globalisation ${ }^{98}$. While it would be pointless to go over the same questions here, what is worth noting, in concluding this analysis, is the special place occupied by the turning point of the 1970s in the emergence of these new historiographical sensibilities. Historians of globalisation have rightly criticised 'presentist' understandings of the phenomenon that single out the last four decades for their alleged uniqueness, and have proposed alternative periodisations that take into account longer-term origins and developments ${ }^{99}$. Yet it is

${ }^{44}$ Akira Iriye, Global and Transnational History: The Past, Present, and Future, (Basingstoke: Palgrave MacMillan, 203), 20-21.

${ }^{95}$ Id., 'Historicizing the Cold War' in, Richard H. Immerman and Petra Goedde, The Oxford Handbook of the Cold War, (Oxford: Oxford University Press, 2015), 16-30 (here: 16-17)

96 Iriye, Global Community; Id., 'The Making of a Transnational World', in Akira Iriye (ed.), Global Interdependence: The World After 1945, (Cambridge, MA, and London: The Belknap Press of Harvard University Press, 2014), 681-847.

${ }^{97}$ Martine van Ittersum and Jaap Jacobs 'Are We All Global Historians Now? An Interview with David Armitage', Itinerario, 36, 2, (2012), 7-28 (here: 16).

${ }^{98}$ See, among many others, Akira Iriye and Pierre-Yves Saunier (eds.), The Palgrave Dictionary of Transnational History, (Basingstoke: Palgrave MacMillan, 2009); Iriye, Global and Transnational History; Dominic Sachsenmaier, Global Perspectives on Global History: Theories and Approaches in a Connected World, (Cambridge: Cambridge University Press, 2011); Kiran Klaus Patel, 'An Emperor without Clothes? The Debate about Transnational History Twenty-Five Years On', Histoire@Politique, 26, (2015); Sebastian Conrad, What Is Global History?, (Princeton, NJ and Oxford: Princeton University Press, 2016).

${ }^{99}$ See Jürgen Osterhammel and Niels P. Petersson, Globalization: A Short History, (Princeton, NJ and Oxford: Princeton University Press, 2005); Michael Lang, 'Globalization and its History', The Journal of Modern History, 
undeniable that a relation does exist between the post-1970s phase of globalisation and new historiographical approaches that focus on interconnectedness and interdependence. Lynn Hunt has described globalisation as an 'ideology' that filled the vacuum left by the exhaustion of the Cold War competition, and which was embraced by scholars who, reacting to the decline of previous historical paradigms and cultural critiques, started to pay increasing attention to the global context of history ${ }^{100}$. David Reynolds has recently commented that the new transnational history represents 'a particularly appropriate response to the post-1970s era, in a world that has become so profoundly shaped by non-state actors - from international capital markets to global corporations, from peace movements to terrorist networks, from movies and popular music to the internet and the world-wide web'. The problem, as he sees it, is rather that this should not lead to considering the states as impotent and therefore irrelevant for historical analysis, since 'the forces of globalization, for all their power, were mediated and often fragmented by state structures - strong and weak, rising and declining, stable and rogue' ${ }^{101}$.

The study of the long 1970s offers a particularly fertile ground for this kind of dual approach. As this article has tried to show, top-down and bottom-up forces interacted in defining the transformative nature of the decade, and it was often out of their dialectical relationship that historical changes emerged and assumed their meaning in a context of 'large scale structured integration', as Sebastian Conrad defines it $^{102}$. A large field of investigation remains open for historians in terms of providing a multi-layered understanding of this turning point, taking into account domestic, interstate and transnational dynamics as well as their global context and reverberations. As a result of the liminal character of the epoch it studies, the 'new international history of the 1970s' could thus become a first example of, or even a model for, the historical analysis of the global era we live in.

78, 4 (2006), 899-931; Adam McKeown, 'Periodizing Globalization', History Workshop Journal, 63 (2007), 218230 .

${ }^{100}$ Lynn Hunt, Writing History in the Global Era, (London and New York: W.W. Norton \& Company, 2014).

${ }^{101}$ David Reynolds, 'Turn, Turn, Turn', Ricerche di Storia Politica, 3, (2016), 265-268.

${ }^{102}$ Conrad, What Is Global History, 67. 